\title{
An Empirical Analysis of Competitiveness on Cities of Sinaloa, Mexico with an Outranking Method
}

\author{
Pavel A. Alvarez Carrillo ${ }^{1}$, Martín León Santiesteban ${ }^{1}$, Diego A. Gastelum Chavira ${ }^{1}$, Luis A. Vega \\ Osuna $^{1}$ \\ ${ }^{1}$ Universidad de Occidente, Culiacan, Mexico \\ pavel.alvarez@udo.mx, martin.leon@udo.mx, luisalfredo86@yahoo.com.mx, diego.gastelum@udo.mx
}

\begin{abstract}
This work aims to develop an Empirical Analysis of Destination Competitiveness of three main cities of Sinaloa, Mexico with a well-known Crouch-Ritchie model. This problem is approached as a multicriteria ranking problem with an outranking method and a multicriteria group decision support system to generate a ranking of main cities on Sinaloa. The Crouch-Ritchie model is used to generate information to evaluate Destination Competitiveness and the outranking method generates a preferential model and obtains destination competitiveness based ranking of cities.
\end{abstract}

Keywords: Destination Competitiveness, Tourism Destination, Outranking Method, Multiobjective Optimization.

\section{Introduction}

In nowadays world economy, and specifically tourism, major changes occur, which require competitiveness analysis tools for private and public sectors. In this matter, our objective is to analyze the competitiveness of three tourist destinations with a well-known model for destination competitiveness, using an outranking method to generate a ranking of alternatives in decreasing preference order. The outranking method for this empirical analysis is the ELECTRE III and is used as a tool to construct the preferential model with the information obtained by the Crouch-Ritchie model for destination competitiveness. The outranking method is not an alternative model for destination competitiveness evaluation, instead; it is a tool to extend the Crouch-Ritchie model with an objective evaluation of the destinations being compared.

Few studies have attempted to identify strategies for improving Tourism Destination Competitiveness, preventing decision makers from obtaining valuable cues for making accurate decisions to improve Competitiveness (Peng and Tzeng, 2012). In this work, we use the Crouch-Ritchie model as a framework to analyse the destination competitiveness of three main cities in Sinaloa. The destination competitiveness is compared among the cities using the model to obtain 5 main criteria. The procedure of this analysis indicates how to use the attributes to make a comparison among tourism destinations.

\subsection{Sinaloa in the Touristic Context}

When we speak about tourism in Sinaloa, undoubtedly we need to talk about the port of Mazatlan, which is considered as the productive core of the southern part of the state, since it has defined the tourism as one of its economic vocations; activity which the city has emphasized its specialization since the decreasing productivity of fishing and commercial traffic led to the port in recent years. However, we should not leave behind cities like Culiacan and Los Mochis, which are considered commercial and business destinations. In this sense, Sinaloa has a wide range of attractions, which allow it to be considered as a State with an important touristic potential. Some examples are the colonial buildings, the dams, pristine beaches, lagoons for hunting development and traditional cultural expressions.

Therefore, Tourism is considered as the second pillar of the Sinaloa economy after agricultural activities, this because in 2011 it accounted for 12 percent of Gross State Product and is the second source of foreign exchange, with a large multiplier effect investment, income and employment (PED, 2011: 227).

In this sense, the touristic inflow of Sinaloa in 2011 was 2 million 739 thousand tourists, 2.1 percent less than in 2010, of which 311 were 2 million domestic visitors and 428,000 foreigners. (INEGI, 2012).

The hotel infrastructure of Sinaloa, in 2011, was made up of 19,742 rooms in 431 shops, 74.7 percent distributed in Hotels and 10 percent in Motels. The rest consists of guesthouses, cottages, suites, lodges, RV parks, among others. This fact allows the State to occupy the eighteenth place nationally, according to INEGI (2012).

In addition, by category, 7.7 percent are five star hotels, 13.2 percent four stars, 18.8 percent three stars, 9.5 percent two stars and 10.2 percent one star hotels, the remaining 40.6 percent are not yet classified.

There are some projects aimed to pro-mote Sinaloa, which will come to deto-nate the tourism industry and it is as-sumed that with them it could be said that the state will compete with the best desti-nations in Mexico and / or possibly with some countries. These projects are the Espiritu Beach in Escuinapa, the OceArp Las Labradas Park in San Ignacio, the Eco Park Las Marismas, the Sus- 
tainable Model Beach (Togo), The Cortes Island Project (New Altata) in Navolato, Ohuira Bay in Ahome, Mill Park in Los Mochis, Ahome, the Durango-Mazatlan highway, the Baluarte Bicentennial Bridge, as well as real estate development and high-level services in Mazatlan. Furthermore, we have to consider the 29 projects that have been promoted in recent years, which carry considerable progress in Sinaloa tour-ism's development (GES, 2012).

This paper is divided into 4 main sections. In the Section 2 , we describe some destination competitiveness models and some studies of competitiveness developed with Multicriteria Decision Analysis (MCDA). The method of the analysis of destination competitiveness based on Crouch-Ritchie model is described in the Section 3. In the Section 4, an analysis of the destination competitiveness with an outranking method is presented and a sensitive analysis is developed to strengthen our results. Finally, conclusions are presented in the Section 5.

\section{Related work}

There are a lot studies developed in destination competitiveness. However, some few are developed with MCDA methods. In this section we explain tourism competitiveness models and relevant works developed with MCDA methods.

\subsection{Analysis of Tourism Competitiveness Models}

Regarding the models that analyze the factors that can determine whether a destination is more competitive in relation to another, there are some approaches focused on destination competitiveness. In this section, we describe the approaches proposed by Porter (1998) and Crouch (2010). Also, we will highlight the definition of competitiveness by Dwyer and Kim (2003).

Porter's Approach (1998) is not focused on the study of enterprises. Rather, it studies countries or destinations, because its main idea distinguishes that the success of a company depends not only on the strategy and positioning, but also on the environment. It also considers destinations as "clusters" due to the success of a particular sector, where the environment is dynamic, challenging and encourages businesses to improve their advantage.

According to Porter, economic competitiveness is based on the determinants of competitive advantage, which considers four main attributes and two secondary. The first one, the condition of the factors, incorporates the basic components of tourism product, which determine the attractiveness of a destination and are proposed in three categorizations: 1) natural and cultural resources, 2) capital and infrastructure and 3) human resources. The second one, the demand conditions are determined by: 1) the size of the potential market, 2) the characteristics of the market, 3) positioning in growth markets and 4) for sophisticated tourists: recognize new trends.
Third one, bidders-related industries 'direct offer': 1) access to the destination, 2) food, entertainment, 3) souvenir industry, 4) quality services, 5) suppliers, 6) education and training centers and 7) health centers.

And finally, Structure, Organization and Strategy: the key element of this determinant is the availability of a strategic tourism plan. In this sense, there are also different ways to run a company or a destination. Here the strategy is to find the best one.

On the other hand, Crouch (2010) states that, "the tourism product is an experience that is delivered by a destination to the visitors". This means that the additional complexity of the product itself consists of a greater number of attributes, which ensures that each visitor takes home a unique experience.

At the same time, there are many different objectives that lie behind the policy of private and public tourism. While some goals address the economic return and profit, other objectives concern the environmental and social context. In this way the management of the destination competitiveness lies not only in one business but in all the participants that impact visitors in their experience, just like tourism enterprise should be, like the support enterprises that include the organizations.

Crouch (2010) notes that the management of the destination competitiveness has become a subject of interest because of the theories, models and processes that can guide the approach to this challenge, as they offer the possibility of place with clarity and rigor a complex management task.

On the other hand, it impresses that the impact of an attribute of the competitiveness in the relative performance of a destination is a function as long as the importance of the attribute is variable in the destination.

This Crouch-Ritchie model (2010) is accentuated mainly on two factors that recognize the complexity of the destination, which is based on resource endowments of a destination (comparative advantage), as well as its ability to deploy resources (competitive advantage) and get the impact of macroeconomic and microeconomic environment. The term destination competitiveness according to Dwyer and Kim (2003) can be defined as "the relative ability of a destination to meet the needs of visitors in the various aspects of the tourism experience".

\subsection{Studies of Competitiveness with MCDA methods}

Peng and Tzeng (2012) explored strategies for improving tourism competitiveness implementing a MCDM model and combining DEMATEL - based ANP. Mazanec, Wober and Zins (2007) developed a research regarding with the tourism destination competitiveness including the gargantuan compilations of competitiveness factors than include Ritchie and Crouch (2003), Dwyer and Kim (2003) and Competitiveness Monitor initiated by the World Travel and Tourism Council. With an empirical study, they found that is possible with the Competitiveness monitor model explain the levels of tourism activity 
better than sustained tourism growth. Furthermore, they made recommendations on how to adjust the future strategy of research on destination competitiveness.

\section{Method}

In this work, we are interested in analyzing the main cities of Sinaloa, Mexico with a destination competitiveness approach. Thus, we used the Crouch-Ritchie model to analyze three cities as a tourism destination. For rank the destinations we use the well-known ELECTRE III methodology as an outranking method for this multicriteria ranking problem.

The outranking methods (e.g., ELECTRE methods) presents a natural heuristic approach based on the concordance and discordance principles where the majority rules are combined with respect to significant minorities. This outranking method has the ability to deal with uncertain and fuzzy information.

Figueira, Greco and Roy (2009) assert two main important advantages of using outranking methods. The firs advantage is that they are able to take purely ordinal scales into account (Martel and Roy, 2006), without needing to convert the original scales into abstract ones with an arbitrary imposed range, thus maintaining the original concrete verbal meaning.

A second advantage is that indifference and preference thresholds can be taken into account when modeling the imperfect knowledge of data, which is not feasible in the methods: AHP, MACBETH MAUT, SMART and TOPSIS.

In empirical analysis of destination competitiveness of three cities of Sinaloa, Mexico, we use information obtained from the Statistical and Geographic National Institute in Mexico (INEGI -acronym in Spanish).

In total, the Crouch-Ritchie model identifies 36 destination competitiveness attributes. However, the information founded in INEGI (2012) let us use 45 attributes regarded to the five main factors of the model, which were used as criteria in the outranking method.

The factor Core Resources and Attractors is show in the Table 1. This factor regards natural resource as well as attractions of structure. Table 2 presents the information regarding Destination Management. Table 2 shows indicators about the organization of the governmental agencies of tourism. The factor of Destination Policy, Planning and Development regards the management and development of tourism by the governmental agencies. This factor must monitor and evaluate the capacities of the hotels (see Table 3). The factor Qualifying and Amplifying Determinants is measured in terms of geographical, territorial and population information (see Table 4). The factor Supporting factors and resources regards the roads and transportation capabilities, travel agencies and hotels capabilities (see Table 5).

Table 1: Factor of Core Resources and Attractors.

\begin{tabular}{|c|c|c|c|}
\hline \multirow{2}{*}{$\begin{array}{l}\text { Core Resources and Attractors } \\
\text { Nature }\end{array}$} & \multirow[t]{2}{*}{ Ahome } & \multicolumn{2}{|c|}{ Culiacan Mazatlan } \\
\hline & & & \\
\hline Watercourse & 8 & 20 & 14 \\
\hline Dams & 2 & 3 & 1 \\
\hline Thermal spring & 1 & 1 & 1 \\
\hline Temperature & 25.9 & 25.6 & 24.7 \\
\hline *Especial events & 30 & 30 & 30 \\
\hline \multicolumn{4}{|l|}{ Entertainment } \\
\hline Hunting and fishing & 1 & 1 & 1 \\
\hline Colonial buildings & 1 & 1 & 1 \\
\hline Archaeological sites & 1 & 1 & 1 \\
\hline \multicolumn{4}{|l|}{ Super-structure } \\
\hline Shopping center & 1 & 1 & 1 \\
\hline Conglomerate hotels & 1 & 1 & 1 \\
\hline Association of hotels & 1 & 1 & 1 \\
\hline Market ties & 175,051 & 430,614 & $1,239,091$ \\
\hline Foreign tourism & 16,263 & 7,566 & 270,997 \\
\hline Domestic tourism & 158,788 & 423,048 & 968,114 \\
\hline
\end{tabular}

Table 2: Factor of Destination Management.

\begin{tabular}{lrrr}
\hline Destination Management & \multicolumn{3}{c}{ Ahome Culiacan Mazatlan } \\
\hline Organization & 1 & 1 & 1 \\
Secretary for Tourism & 1 & 1 & 1 \\
Municipal Direction for tour- 1 & 1
\end{tabular}




$\begin{array}{lrrr}\text { ism } & & \\ \begin{array}{l}\text { Council for economic devel- } 1 \\ \text { opment }\end{array} & 1 & 1 \\ \text { Car rental } & 5 & 6 & 13\end{array}$

Table 3: Factor of Destination Policy, Planning and Development.

\begin{tabular}{llll}
\hline $\begin{array}{l}\text { Destination Policy, Planning and Develop- Ahome Culiacan Mazatlan } \\
\text { ment }\end{array}$ & 3 & 3 & 3 \\
\hline Time to election of delegates & 5 & 5 & 10 \\
$\begin{array}{l}\text { Development of new projects } \\
\text { Monitoring and evaluation for hotels }\end{array}$ & & & \\
$\quad$ Average rooms & 1,276 & 2,147 & 9,143 \\
$\quad$ Available rooms & 39,556 & 66,557 & 283,430 \\
$\quad$ Rooms in use & 14,732 & 28,424 & 125,589 \\
$\quad$ Occupancy rate \% & 37.24 & 42.71 & 44.31 \\
\hline
\end{tabular}

Table 4: Factor of Qualifying and Amplifying Determinants.

\begin{tabular}{|c|c|c|c|}
\hline Qualifying and Amplifying Determinants & Ahome & Culiacan & n Mazatlan \\
\hline *Latitude & \multicolumn{3}{|c|}{$32^{\circ} 43^{\prime}-14^{\circ} 32^{\prime} \mathrm{N}$} \\
\hline Longitude & $109^{\circ} 0^{\prime} \mathrm{O}$ & $\begin{array}{l}107^{\circ} 2 ? \\
\mathrm{O}\end{array}$ & $\begin{array}{l}3^{\prime} 106^{\circ} \quad 25 \\
\mathrm{O}\end{array}$ \\
\hline Altitl & 10 & 60 & 10 \\
\hline arity \% & 0.72 & 0.72 & 0.72 \\
\hline monthly salary & 6,453 & 9,278 & 5,775 \\
\hline Total population & 416,299 & 858,638 & 438,434 \\
\hline Territorial percentage & 6.9 & 10.9 & 4.4 \\
\hline
\end{tabular}

* Latitude is the same for every destination

Table 5: Factor of Supporting and Resources.

\begin{tabular}{llll}
\hline Supporting factors and resources & Ahome & Culiacan & Mazatlan \\
\hline International airports & 1 & 1 & 1 \\
Passengers in commercial flies & 221,800 & $1,077,308$ & 701,085 \\
Direct aerial destinations & 8 & 16 & 25 \\
Roads (Km.) & 2,939 & 2,573 & 636 \\
Travel agency & 22 & 49 & 65 \\
Car rental & 5 & 6 & 3 \\
Marine tourism & 0 & 0 & 2 \\
Hotels & 31 & 61 & 145 \\
Rooms & 1,490 & 3,036 & 9,331 \\
Restaurants & 50 & 175 & 137 \\
Restaurant bar & 44 & 32 & 140 \\
Coffee shop & 6 & 15 & 6 \\
Bars & 8 & 14 & 11 \\
Museums & 13 & 5 & 43 \\
\hline & Fernandez (2003) and a multiobjective evolutionary algo- \\
& rithm (Leyva and Aguilera, 2005). The system is availa- \\
tion Competitiveness with & ble on the page http://mcdss.udo.mx/xgdss (see Fig. 1 and \\
& Fig. 2).
\end{tabular}

\section{Analysis of the Destination Competitiveness with an Outranking Method}

The described problem was treated with a Multi-criteria group decision support system named SADGAGE (Alvarez and Leyva, 2012) (acronym in Spanish). The SADGAGE system was designed based on a multicriteria methodology for the ranking problem that uses the ELECTRE III method (Roy, 1990) for modeling the group preferences with a method developed by Leyva and 


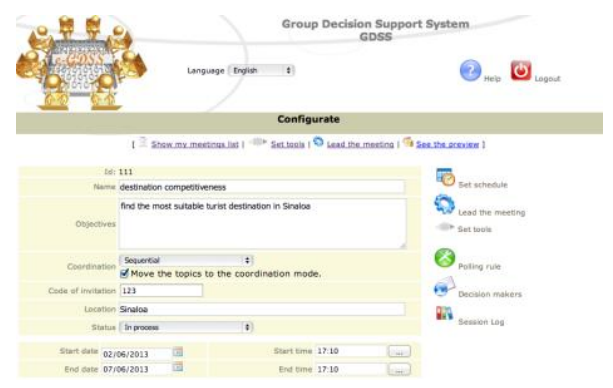

Fig. 1: Configuration of a multicriteria ranking project on SADGAGE.

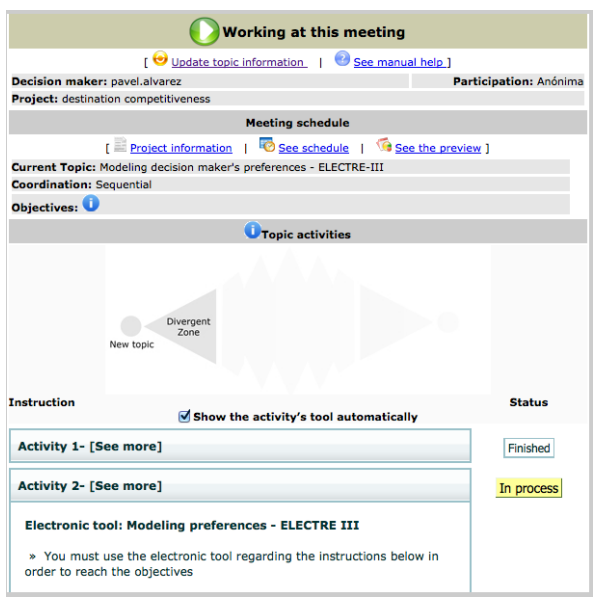

Fig. 2: Development of the decision process on SADGAGE.

Based on Crouch and Ritchie (2011) we rank three local cities of Sinaloa. In this section we solved a multi-criteria ranking problem which aims to find the most competitiveness destination on Sinaloa, Mexico.

There are three most important cities in Sinaloa; Los Mochis (Ahome), Culiacan and Mazatlan. Los Mochis is one of the biggest agriculture zones of the country. It has one of the most fertile valleys on the world. Culiacan is the capital and the most important city of the Sinaloa state. Mazatlan is one of the most important beach touristic destinations in Mexico.

We have three cities to evaluate their competitiveness with Crouch and Ritchie (2011) model (see Table 6).

Table 6: Alternatives or destinations to evaluate.

\begin{tabular}{ll}
\hline Code & Destination \\
\hline A1 & Ahome \\
A2 & Culiacan \\
A3 & Mazatlan \\
\hline
\end{tabular}

Crouch and Ritchie (2011) conceptual model of destination competitiveness presents a vast list of attributes to evaluate competitiveness destinations. In total there are
36 factors to be considered. They represent five main factors. To adapt Crouch and Ritchie (2011) model and evaluate the three most important destinations in Sinaloa we modified some attributes deleting and adding them. The model considers the Qualifying and Amplifying Determinants; Destination Policy, Planning and Development; Destination Management; Core Resources and Attractors; and Supporting Factors and Resources.

However, due to the lack of data, we use a different factor named sustainable management of the environment. Then the criteria to evaluate destination competitiveness are showed in Table 7. Table 8 shows the values of each alternative (destination) with respect to each criterion, this is the performance matrix.

Table 7: Criteria to evaluate destinations.

\begin{tabular}{ll}
\hline Code & Criterion \\
\hline C1 & Core Resources and Attractors \\
C2 & $\begin{array}{l}\text { Destination Management } \\
\text { Destination Policy, Planning } \\
\text { and Development }\end{array}$ \\
C4 & $\begin{array}{l}\text { Qualifying and Amplifying } \\
\text { Determinants } \\
\text { Supporting factors and re- } \\
\text { C5 }\end{array}$ \\
&
\end{tabular}

Table 8: Performance of the alternatives.

\begin{tabular}{l|lllll}
\hline & C1 & C2 & C3 & C4 & C5 \\
\hline A1 & 29 & 30 & 18 & 28 & 20 \\
A2 & 36 & 32 & 22 & 48 & 34 \\
A3 & 35 & 38 & 59 & 24 & 46 \\
\hline
\end{tabular}

According to ELECTRE III methodology (e.g. Roy 1990) the following choices of weights, indifference and strict preference thresholds associated to each criterion were made (see Table 9). In this problem the DMs are not considered using the veto threshold.

Table 9: Pseudo-criteria parameters: weights, indifference and preference thresholds.

\begin{tabular}{l|lllll}
\hline & $\mathrm{C} 1$ & $\mathrm{C} 2$ & $\mathrm{C} 3$ & $\mathrm{C} 4$ & $\mathrm{C} 5$ \\
\hline $\mathrm{w}$ & 0.3 & 0.1 & 0.2 & 0.1 & 0.3 \\
$\mathrm{q}$ & 3 & 3 & 5 & 4 & 5 \\
$\mathrm{p}$ & 6 & 5 & 10 & 10 & 10 \\
\hline
\end{tabular}

$w$ is the weight of the criterion

$q$ is the indifference threshold of the criterion

$p$ is the preference threshold of the criterion

According to the additional information pointed out before, for the decision maker we applied ELECTRE III to construct a valued outranking relation. Afterwards, we used the evolutionary algorithm presented in Leyva and Aguilera (2005) to exploit the outranking relation and derive a final ranking of the alternatives in decreasing order of preferences. 
The modeling individual preference step results in a valued preference relation. The preferences outcome is called Credibility Matrix and they are presented in Table 10.

Table 10: Credibility Matrix.

\begin{tabular}{llll}
\hline & A1 & A2 & A3 \\
\hline A1 & 1 & 0.3 & 0.1 \\
A2 & 1 & 1 & 0.4 \\
A3 & 1.0 & 0.9 & 1 \\
\hline
\end{tabular}

Once it is obtained the decision maker's preference model (credibility matrix), the next step is its exploitation in order to obtain a ranking of alternatives. To do that, we used a heuristic method based on multiobjective evolutionary algorithms (MOEA), which was presented in Leyva and Aguilera (2005).

As we said before, we used SADGAGE software, which has implemented the MOEA to derive a ranking of alternatives; the parameters defined for it are shown as follow:

- Number of generations: 10,000

- Population size: 30

- Crossover probability: 0.95

- Mutation probability: 0.05.

The restricted Pareto front, $P F_{\text {known }}^{\text {restricted }}$, found and the associated final set of solutions returned by the MOEA, $P_{\text {known }}^{\text {restricted }}$, are presented in Table 11 .

Table 11: Restricted Pareto front found and the associated individuals of the solutions space.

\begin{tabular}{ccccccc}
\hline Ranking & $\tilde{p}_{1}$ & $\tilde{p}_{2}$ & $\tilde{p}_{3}$ & $\tilde{p}_{4}$ & $\tilde{p}_{5}$ & $\tilde{p}_{6}$ \\
\hline 1 & $A_{3}$ & $A_{3}$ & $A_{3}$ & $A_{3}$ & $A_{3}$ & $A_{3}$ \\
2 & $A_{2}$ & $A_{2}$ & $A_{2}$ & $A_{2}$ & $A_{2}$ & $A_{2}$ \\
3 & $A_{1}$ & $A_{1}$ & $A_{1}$ & $A_{1}$ & $A_{1}$ & $A_{1}$ \\
\hline$u$ & 0 & 0 & 0 & 0 & 0 & 0 \\
$f$ & 0 & 0 & 0 & 0 & 0 & 0 \\
$\lambda$ & 0.899 & 0.899 & 0.899 & 0.899 & 0.899 & 0.899 \\
Fitness & 27.5 & 27.5 & 27.5 & 27.5 & 27.5 & 27.5 \\
\hline
\end{tabular}

Notes:

$\widetilde{p}_{i}$ is an individual (solution) associated to the members of the final restricted Pareto front.

- $\quad A$ - Ahome, $A$ - Culiacán, $A_{3}$ - Mazatlán

- $\quad u, f$, and are the objective functions of the MOEA

The MOEA was executed 50 times with the parameters described above. The outputs of the algorithm are shown in Table 12, which presents the number of times that an alternative was found at a certain place in the ranking. As each position in the order has assigned a weight $w_{i}$, we calculate the weighted sum ${ }_{i=1}^{m} w_{i} T(i, j), j=1 . ., m$, with which we obtained the final recommendation to the decision maker. As noted, the alternatives at all times retained their position in the ranking with a credibility level of
.8999 , which being close to 1.0 gives greater certainty of the outcome.

Table 12. The number of times that an alternative was found at a certain place in the ranking.

\begin{tabular}{ccccc} 
Weight $\boldsymbol{w}_{\boldsymbol{i}}$ & Rank & $A_{1}$ & $A_{2}$ & $A_{3}$ \\
\hline 3 & 1 & 0 & 0 & 50 \\
2 & 2 & 0 & 50 & 0 \\
1 & 3 & 50 & 0 & 0 \\
\hline$\sum_{i=1}^{m} w_{i} T(i, j)$ & & & & \\
\hline Minimum $\lambda:$ & & & & \\
\hline
\end{tabular}

Finally, Table 12 suggests the final ranking shown in Table 13

Table 13: Ranking of the alternatives.

\begin{tabular}{lll}
\hline Position & Code & Destination \\
\hline 1 & A3 & Mazatlan \\
2 & A2 & Culiacan \\
3 & A1 & Ahome \\
\hline
\end{tabular}

\subsection{Sensitivity Analysis}

After obtaining a recommendation to the decision maker, and even if this is accepted, the decision process is not necessarily is finalized. Additionally, the analyst can propose to undertake a sensitivity analysis. A sensitivity analysis is to measure the robustness of an optimal solution based on changes in the values of the decision maker's preferences. This analysis allows us to interpret the results from the modification of the values of the weights and/or thresholds of indifference, preference. For this, the decision maker provides a range of values consistent even considering their preferences. A proposal about how to perform this kind of analysis on the weights of the criteria and the performance values of the alternatives is presented by Triantaphyllou and Sánchez (1997). Examples where the implementation of a sensitivity analysis can be found in Briggs et al., (1990); Goicoechea et al., (1982), Rios Insua and French, (1991), Leyva (2005) and Leyva and Gastelum, (2013).

A sensitivity analysis can be addressed by changing values on the following parameters:

Change in the values of the relative importance $(w)$ in just one criterion,

Change in the values of the relative importance $(w)$ in several criteria,

Change in the values of indifference $(I)$ and/or preference $(P)$ thresholds in just one criterion, and 
Change in the values of indifference $(I)$ and/or preference $(P)$ thresholds in several criteria.

The outcomes of the sensitivity analysis for this empirical study are shown in Table 14.

Table 14. Influence of changes in specific parameters and changing values in the selected parameters on the final result.

\begin{tabular}{|c|c|c|c|c|}
\hline \multirow[t]{2}{*}{$\begin{array}{l}\text { Range of } \\
\text { changes }{ }^{\dagger}\end{array}$} & \multirow[t]{2}{*}{$\begin{array}{l}\text { Assumed } \\
\text { changes }^{\dagger \dagger}\end{array}$} & \multicolumn{3}{|c|}{$\begin{array}{c}\text { Final } \\
\text { results }^{\S}\end{array}$} \\
\hline & & $A_{3} A_{2} A_{1}$ & $A_{2} A_{3} A_{1}$ & Minimum $\lambda$ \\
\hline \multirow{13}{*}{$\begin{array}{l}\text { 1. Change in } \\
\text { the values of } \\
\text { the relative } \\
\text { importance }(w) \\
\text { for two or more } \\
\text { criteria simul- } \\
\text { taneously }\end{array}$} & $\begin{array}{l}\text { C1: } w 1=0.2 \\
\text { C2: } w 2=0.2\end{array}$ & 5 & 0 & 0.8999 \\
\hline & $\begin{array}{l}\text { C1: } 1=0.25 \\
\text { C3: } 3=0.25\end{array}$ & 5 & 0 & 0.8999 \\
\hline & $\begin{array}{l}\text { C3: } w 3=2.5 \\
\text { C5: } w 5=2.5\end{array}$ & 5 & 0 & 0.8999 \\
\hline & $\begin{array}{l}\text { C2: } 2=0.15 \\
\text { C3: } 3=0.15\end{array}$ & 5 & 0 & 0.8999 \\
\hline & $\begin{array}{l}\text { C3: } 3=0.15 \\
\text { C4: } 4=0.15\end{array}$ & 5 & 0 & 0.8499 \\
\hline & $\begin{array}{l}\text { C2: } w 2=0.2 \\
\text { C5: } w 5=0.2\end{array}$ & 5 & 0 & 0.8999 \\
\hline & $\begin{array}{l}\text { C4: } w 4=0.2 \\
\text { C5: } w 5=0.2\end{array}$ & 5 & 0 & 0.7999 \\
\hline & $\begin{array}{l}\mathrm{C} 1: w 1=0.1 \\
\mathrm{C} 2: w 2=0.3\end{array}$ & 5 & 0 & 0.8999 \\
\hline & $\begin{array}{l}\text { C4: } w 4=0.3 \\
\text { C5: } w 5=0.1\end{array}$ & 5 & 0 & 0.6999 \\
\hline & $\begin{array}{l}\mathrm{C} 1: w 1=0.25 \\
\mathrm{C} 2: w 2=0.2 \\
\mathrm{C} 5: w 5=0.25\end{array}$ & 5 & 0 & 0.8999 \\
\hline & $\begin{array}{l}\text { C1: } w 1=0.25 \\
\text { C4: } w 4=0.2 \\
\text { C5: } w 5=0.25\end{array}$ & 5 & 0 & 0.7999 \\
\hline & $\begin{array}{l}\text { C2: } w 2=0.15 \\
\text { C3: } w 3=0.1 \\
\text { C4: } w 4=0.15\end{array}$ & 5 & 0 & 0.8499 \\
\hline & $\begin{array}{l}\mathrm{C} 1: w 1=0.2 \\
\mathrm{C} 2: w 2=0.2 \\
\mathrm{C} 3: w 3=0.2 \\
\mathrm{C} 4: w 4=0.2 \\
\mathrm{C} 5: w 5=0.2\end{array}$ & 5 & 0 & 0.7999 \\
\hline \multirow{5}{*}{$\begin{array}{l}\text { 2. Change in } \\
\text { the values of } \\
\text { the } q \text { and } p \\
\text { thresholds for a } \\
\text { single criterion }\end{array}$} & $\begin{array}{l}\text { C1: } \\
q=3.5, p=5.5\end{array}$ & 5 & 0 & 0.8999 \\
\hline & $\begin{array}{l}\mathrm{C} 2: \\
q=3.5, p=4.5\end{array}$ & 5 & 0 & 0.8999 \\
\hline & $\begin{array}{l}\text { C3: } \\
q=6.5, p=8.5\end{array}$ & 5 & 0 & 0.8999 \\
\hline & $\begin{array}{l}\text { C4: } \\
q=6, p=8\end{array}$ & 5 & 0 & 0.8999 \\
\hline & $\begin{array}{l}\text { C5: } \\
q=7, p=8\end{array}$ & 5 & 0 & 0.8999 \\
\hline \multirow{3}{*}{$\begin{array}{l}\text { 3. Changes in } \\
\text { the values of } q \\
\text { and } p \text { for mul- } \\
\text { tiple criteria } \\
\text { simultaneously. }\end{array}$} & $\begin{array}{l}\mathrm{C} 1: \\
q=4, p=5 \\
\mathrm{C} 4: \\
q=6, p=8\end{array}$ & 5 & 0 & 0.8999 \\
\hline & $\begin{array}{l}\mathrm{C} 2: \\
q=3.5, p=4.5 \\
\mathrm{C} 4: \\
q=6, p=8\end{array}$ & 5 & 0 & 0.8999 \\
\hline & $\begin{array}{l}\text { C1: } \\
q=4, p=5 \\
\text { C } 3: \\
q=7, p=8 \\
\text { C } 5: \\
q=7, p=8\end{array}$ & 5 & 0 & 0.8999 \\
\hline
\end{tabular}

Notes:

$\dagger$ Range of changes of specific parameters related to the decision maker's preferences.

i† Assumed changes in parameter values.

$\S$ Final results after the changes in parameters have been introduced.

For each single of the 21 experiments where were changed weights or thresholds, on one or more criteria, were performed five executions of the MOEA, i.e., the MOEA was executed 105 times, and as can be seen in Table 14, the rankings obtained were $100 \%$ consistent with the final recommendation shown in Table 13.

The process of decision finalizes with the sensitivity analysis. The process is long and ultimately is the decision maker who makes an assessment of whether the presented recommendation is according to their preferences or not; but with this methodology various real-world problems can be addressed obtaining good outcomes.

\section{Conclusion}

This work presents an empirical analysis of a well-know Crouch-Ritchie model to determine the destination competitiveness of three cities of Sinaloa, Mexico. The ranking of the cities was developed with an outranking method comparing the attributes that reflect the destination competitiveness.

The results of the ranking hold constants because Mazatlan city presents higher attributes and values of tourism compared with the rest of cities in terms of competitiveness. However, this empirical analysis can be considered as a first prototype of procedure to use the Crouch-Ritchie model in the multicriteria ranking problem for evaluation of competitiveness in tourism destination.

For future works, this procedure could be used to evaluate the competitiveness of others tourism destinations and identify which factors can be more attractive for tourism.

\section{References}

[1] P. Alvarez and J. Leyva, "Sistema de apoyo a la decisión multicriterio en grupo: influencia de la coordinación paralela y secuencial en la actuación de un grupo colaborativo". In: Proceedings of the XVI LatinIberian-American Congress on Operational Research (CLAIO), pp. 4758-4769, Río de Janeiro, Brazil, 2012.

[2] T. Briggs, P. Kunsch, and B. Mareschal, "Nuclear Waste Management: An Application of the Multicriteria PROMETHEE Methods". European Journal of Operational Research 44(1), pp. 1-10, 1990.

[3] G. Crouch, "Destination Competitiveness: An Analysis of Determinant Attributes", Journal of Travel Research, 50: 27, 2010. 
[4] L. Dwyer and C. Kim, "Destination Competitiveness: Determinants and Indicators", Current Issues in Tourism, pp. 369-414, 2003.

[5] J. Figueira, S. Greco, B. Roy "ELECTRE methods with interaction between criteria: An extension of the concordance index", European Journal of Operational Research, 199 (2), pp. 478-495, 2009.

[6] A. Goicoechea, D. Hansen, L. Duckstein, "Multiobjective Decision Analysis with Engineering and Business Applications". J. Wiley, New York, 1982.

[7] J. Leyva, "Multicriteria Decision Aid Application to a Student Selection Problem". Pesquisa Operacional, 25, pp. 45-68, 2005.

[8] J. Leyva, M. Aguilera, "A Multiobjective Evolutionary Algorithm for Deriving Final Ranking from a Fuzzy Outranking Relation", in: C. Coello Coello, E. Zitzler, A. Hernández (Eds.) Evolutionary MultiCriterion Optimization. "Third International Conference", EMO 2005, Lecture Notes in Computer Science 3410 Springer, Berlin Heidelberg, 2015.

[9] J. Leyva, E. Fernández, "A New Method for Group Decision Support Based on ELECTRE-III Methodology". European Journal of Operational Research, 148:1, 2003.

[10] J. Mazanec, K. Wober, A. Zins, "Tourism Destination Competitiveness: From Definition to Explanation?", Journal of Travel Research, 46, pp 86-95, 2007.

[11] National Institute of Statistics, Geography and Informatics. "Statistical Yearbook of the State of Sinaloa". INEGI, Mexico, 2012.

[12] K. Peng and G. Tzeng, "Intelligent Decision Technologies" In: J. Watada, T. Watanabe, G. Phillips-Wren, R. Howlett, L. Jain (Eds.), Strategies for Promoting Tourism Competitiveness Using a Hybrid MCDM Model, pp 107-115, Springer Berlin Heidelberg, 2012.

[13] M. Porter, "The competitive advantage of nations". Nueva York: The Free Press, 1998.

[14] D. Rios, S. French, "A framework for sensitivity analysis in discrete multiobjective decision-making", European Journal of Operational Research. 54, pp. 176-190, 1991.

[15] B. Roy, "The Outranking Approach and the Foundations of ELECTRE Methods", in: Bana e Costa CA (Ed.) Reading in Multiple Criteria Decision Aid, Springer-Verlag, Berlin, 1990.

[16] Sinaloa State Government. "First Government report, 2011", ed. Sinaloa State Government, 2012.

[17] Sinaloa State Government, "Tourism Sector Program of the State of Sinaloa, 2011-2016", Culiacan, Sinaloa, 2012.

[18] E. Triantaphyllou, A. Sanchez, "A Sensitivity Analysis Approach for Some Deterministic Multi-Criteria Decision-Making Methods". Decision Sciences, 28, pp. 151-194, 1997. 